\title{
Formulasi Strategi Pembinaan Remaja Masjid Al-Falah Kelurahan Latsari Tuban
}

\author{
Yayah Komariyah, Ahmad Khairul Hakim \\ Universitas Islam Negeri SunanAmpel Surabaya \\ yayah.komariy14@gmail.com, khairul.hakim@uinsby.ac.id
}

\begin{tabular}{l}
\hline Article Info \\
\hline Article history: \\
Received 15 Mei 2021 \\
Accepted 15 Juni 2021 \\
Published 22 Juli 2021 \\
Page : 78 - 90 \\
\hline
\end{tabular}

\section{Keyword:}

Formulasi Strategi, Pembinaan Remaja Masjid

\begin{abstract}
The problem examined by this study is how the process strategy planning in the founding of Islamic Youth of Al-Falah Mosque in Latsari Tuban and what the content of planning the founding strategy. The research aims to illustrate how the Islamic Youth of Al-Falah Mosque in Latsari Tuban does to prepare strategy planning in the founding of Islamic youth and also to find out the content of planning the founding strategy. To describe that two problems, researcher used a qualitative method with case study. The data was dig deep with interview techniques, observation, and documentation. The research provided the following results. First, in strategy planning process, the Islamic Youth of Al-Falah Mosque used external analysis, then formulated vision for the next five years, discussion with core functionaries, then rediscuss to all of organization's devisions and praying together. Second, the design of Islamic Youth founding strategy was that there was a formulation of a target program of activities, measuring activity program's and also developes the activity by adding new activity programs.
\end{abstract}

Rumusan masalah yang dikaji dalam penelitian ini adalah bagaimana proses penyiapan rencana strategi dalam pembinaan Remaja Masjid AlFalah Kelurahan Latsari Tuban dan apa isi dari rencana strategi dalam pembinaan Remaja Masjid Al-Falah tersebut. Tujuan penelitian ini adalah untuk menggambarkan bagaimana Remaja Masjid Al-Falah Kelurahan Latsari Tuban melakukan proses penyiapan rencana strategi pembinaan Remaja Masjid Al-Falah serta untuk menemukan isi dari rencana strategi dalam pembinaan Remaja Masjid Al-Falah. Penelitian ini menggunakan metode kualitatif dengan pendekatan studi kasus. Untuk mendeskripsikan kedua persoalan tersebut, peneliti menggunakan metode kualitatif dengan pendekatan studi kasus. Data-data digali secara mendalam dengan teknik wawancara, observasi dan dokumentasi. Hasil penelitian ini menunjukkan, bahwa pertama, dalam proses penyiapan rencana strategi, Remaja Masjid Al-Falah menggunakan analisis lingkungan eksternal terlebih dahulu, merumuskan visi untuk jangka lima tahun ke depan, musyawarah oleh badan pengurus harian remaja masjid kemudan musyawarah bersama semua devisi dan berdoa. Kedua, isi dari perencanaan strategi pembinaan Remaja Masjid Al-Falah adalah adanya perumusan target program kegiatan, pengukuran pencapaian program kegiatan dan pengembangan kegiatan dengan menambah program kegiatan baru.

Copyright (C) 2021 Journal Of Islamic Management. All rights reserved.

\section{Editorial Office:}

Program Studi Manajemen Dakwah, Fakultas Dakwah dan Komunikasi, UIN Sunan Ampel Surabaya.

Jl. Ahmad Yani 117 Surabaya, Jawa Timur, Indonesia.

Email: jim@uinsby.ac.id 


\section{Pendahuluan}

Formulasi strategi merupakan proses awal manajemen strategi sebelum implementasi strategi dilakukan. Formulasi strategi dilakukan untuk mencapai tujuan organisasi. Formulasi strategi diartikan sebagai proses penyiapan rencana strategi dengan menganalisis lingkungan terlebih dahulu. Formulasi strategi mengarah pada proses menganalisis lingkungan eksternal maupun internal yang meliputi aspek kekuatan, kekurangan, peluang dan ancaman terhadap organisasi. Setelah kegiatan analisis tersebut dilakukan, langkah selanjutnya adalah pembentukan visi serta tujuan akhir, sehingga sasaran organisasi lebih terarah. ${ }^{1}$ Tanpa perencanaan strategis, tujuan organisasi pun akan sulit untuk dicapai.

Apabila suatu organisasi melakukan penelitian terdahulu terhadap lingkungan internal maupun eksternal, maka ia akan mudah untuk mencapai tujuan. Selain itu, organisasi juga akan mudah mengalokasikan sumber daya, menanggulangi berbagai resiko serta mengoptimalkan segala potensi maupun peluang yang ada.

Oleh karena itu, formulasi strategi dapat digunakan oleh organisasi remaja masjid dalam pembinaan remaja masjid. Pembinaan dapat dilakukan dengan baik, apabila program kegiatan berjalan secara efektif dan efesien. Tujuan pembinaan adalah berubahnya sesuatu yang belum baik menjadi lebih baik. Sehingga pembinaan dapat menciptakan perubahan yang lebih positif. ${ }^{2}$

1 Ismail Nawawi, Manajemen Strategik Sektor Publik, (Jakarta: CV Dwiputra Pustaka Jaya, 2010), hlm. 4.

${ }^{2}$ Muhammad Ilyas, M. Sarbini, dan Ali Maulida, "Upaya Pengurus, Dewan Kemakmuran Masjid (DKM) Dalam Pembinaan Keberagaman Remaja" (Studi Kasus pada Remaja Masjid Ahlul Khoir RT 08 RW 13 Kelurahan Cilebut Timur Kecamatan
Seperti halnya pembinaan para remaja. Melihat remaja merupakan usia yang mengalami berbagai perubahan, baik psikis, bologis maupun fisik. Secara biologis, remaja telah mengalami masa peralihan yaitu antara masa kanak-kanak dengan masa dewasa. Secara individual, kebanyakan remaja kurang bertanggungjawab terhadap karakter pribadinya. Di sisi lain, kaum remaja mempunyai keinginan yang harus segera dipenuhi. Keinginan tersebut akan menimbulkan problematika yang cukup signifikan, terutama problematika terhadap dirinya sendiri. Selain itu, problem remaja juga ditimbulkan oleh remaja itu sendiri dalam rangka penyesuaian diri terhadap lingkungannya. ${ }^{3}$ Sehingga para remaja membutuhkan binaan dalam segala aspek seperti aspek mental, kepribadian, beragama, ilmu pengetahuan, ketrampilan dan juga pengembangan bakat. Maka dari itu, masjid merupakan tempat yang tepat digunakan untuk membina para remaja.

Selain sebagai tempat ibadah, masjid juga dapat digunakan sebagai pusat pengembangan kebudayaan. Sebagai pusat kebudayaan, masjid dapat digunakan sebagai tempat mengajar, belajar, musyawarah, dan juga pertunjukan karya seni. ${ }^{4}$ Selain itu, masjid merupakan tempat yang cocok digunakan untuk membina para remaja, terutama dalam hal karakter, akhlak maupun moral. ${ }^{5}$ Pembinaan para remaja dapat dilakukan dengan berbagai kegiatan masjid melalui organisasi kecil di masjid yaitu Organisasi Remaja Masjid.

Remaja masjid dapat diartikan sebagai organisasi yang mewadahi aktivitas remaja-remaja muslim dalam rangka memakmurkan masjid dan

Sukareja Kabupaten Bogor), Prosiding Al-Hidayah Pendidikan Agama Islam, th. 2016, hlm. 193-201.

3 Anis Fauzi, "Masjid Sebagai Pusat Pembinaan Remaja", Jurnal Al-Qalam, vol. 23, no. 2, th. 2006, hlm. 138-332.

${ }^{4}$ Ibid, hlm. 138-332..

${ }^{5}$ Ibid, hlm. 138-332. 
menyiarkan agama. Remaja masjid sebagai salah satu alternatif yang dapat digunakan sebagai pembinaan para remaja untuk tumbuh menjadi remaja sholeh yang dibutuhkan umat muslim seluruh dunia. Melalui orientasi kemasjidan, keislaman, ketrampilan maupun keilmuwan, organisasi remaja masjid dapat menjadi wadah bagi anggotanya untuk mengembangkan diri, bakat maupun kreativitas mereka di bawah naungan ta'mir masjid melalui berbagai program kegiatan. ${ }^{6}$

Melalui perumusan strategi, maka organisasi remaja masjid akan melihat kondisi lingkungan internal maupun eksternal sebagai evakuasi apakah program yang akan dijalankan sesuai kondisi remaja apakah tidak. ${ }^{7}$ Sehingga dengan perumusan rencana strategi, organisasi remaja masjid akan menemukan strategi yang cocok untuk diimplementasikan dan arah kebijakan apa yang akan dilakukan. Akhirnya tujuan dari pembinaan remaja masjid dapat tercapai.

Sebagaimana organisasi Remaja Masjid Al-Falah mengambil kebijakan dalam pembinaan remaja masjid. Organisasi Remaja Masjid Al-Falah memiliki visi, misi, tujuan maupun program kegiatan yang jelas untuk pembinaan remaja masjid. Melalui visi, organisasi Remaja Masjid Al-Falah mengambil kebijakan yang dapat diterapkan dalam pembinaan para remaja, tentunya hal tersebut sesuai dengan faktor situasi dan kondisi, terutama kehidupan lingkungan di kota bagi remaja, serta keragaman remaja masjid dari kalangan yang berbeda. Kebijakan tersebut tentunya tidak terlepas dari proses perumusan strategi.

Remaja Masjid Al-Falah merupakan salah satu organisasi remaja

${ }^{6}$ Aslati, dkk., "Pemberdayaan Remaja Berbasis Masjid (Studi Terhadap Remaja Masjid di Labuh Baru Barat)", Jurnal Masyarakat Madani, vol. 3, no 2, th. 2018 , hlm. 5. masjid yang berada di masjid tiga besar Kabupaten Tuban. Masjid Al-Falah peringkat pertama dalam lomba kemasjidan tingkat Kabupaten Tuban dan peringkat ketiga sebagai masjid tauladan tingkat Jawa Timur. Berdasarkan observasi di tiga masjid terbesar Tuban, Remaja Masjid Al-Falah yang memiliki manajemen terbaik dalam hal pembinaan remaja masjid. ${ }^{8}$ Hingga saat ini, pembinaan remaja masjid telah diikuti oleh berbagai remaja, baik dari kalangan SMP, SMA, mahasiswa maupun remaja pada umumnya.

Dengan visi mewujudkan Remaja Masjid Al-Falah sebagai generasi muda yang bertaqwa kepada Allah SWT, berakhlak mulia, mandiri, dan bermanfaat bagi sesama manusia. Organisasi Remaja Masjid Al-Falah berusaha untuk mewujudkannya melalui berbagai program kegiatan yang dapat diikuti oleh para remaja, baik itu dari bidang dakwah, PHBI (Perayaan Hari Besar Islam), jurnalistik, perekonomian, pendidikan latihan maupun bakat minat. Keberhasilan pembinaan ini telah menciptakan rasa senang bagi pihakpihak masjid seperti ta'mir masjid. Karena di tengah hiruk pikuknya zaman dan juga semakin hebatnya kemajuan saat ini, organisasi Remaja Masjid Al-Falah mampu menjadi tempat pendidikan bagi para remaja. Bahkan saat ini, Remaja Masjid Al-Falah menjadi tauladan bagi remaja masjid lainnya. Ia memiliki binaan remaja masjid lain dan adanya rasa senang dari remaja masjid lain untuk kolaborasi dengan Remaja Masjid Al-Falah Tuban. Selain itu, sebagian dari anggota Remaja Masjid Al-Falah menjadi seorang guru, mubaligh, tokoh masyarakat dan

\footnotetext{
${ }^{7}$ Nur Hidayah, Manajemen Strategik, (Yogyakarta: LP3EM, Universitas Mumahmmadiyah, 2018), hlm 32.

${ }^{8}$ Observasi pada tanggal 17 November 2020.
} 
sebagainya yang memiliki peran penting di lingkungan masyarakat. ${ }^{9}$

\section{Kajian Pustaka}

\section{Manajemen Strategi}

Manajemen strategi berasal dari dua kata yaitu manajemen dan strategi. Istilah manajemen berasal dari bahasa inggris "to manage" yang berarti mengatur, mengurus atau mengelola. Hasibuan mengatakan manajemen adalah sebuah seni untuk mengatur proses pemanfaatan sumber daya manusia secara efektif yang didukung oleh sumber daya lain dalam organisasi untuk mencapai tujuan tertentu. ${ }^{10}$

Sedangkan strategi berasal dari kata "stratogos". Stratogos berasal dari kata stratos yang berarti militer dan ag yang berarti memimpin. Jadi filosofi strategi ini dahulu diartikan sebagai generalship atau sesuatu yang dikerjakan oleh para jenderal dalam membuat rencana untuk menaklukan musuh dan memenangkan perang. ${ }^{11}$

Oleh karena itu, menurut Whelen dan Hunger, manajemen strategis diartikan sebagai langkah, keputusan, maupun tindakan perusahaan yang menentukan kinerja jangka panjang perusahaan. $^{12}$ Secara umum, manajemen strategis diartikan sebagai proses atau rangkaian kegiatan pengambilan keputusan yang bersifat mendasar dan menyeluruh, disertai penetapan cara melaksanakannya yang dibuat oleh pimpinan dan diimplementasikan oleh seluruh jajaran di dalam suatu organisasi untuk

\footnotetext{
${ }^{9}$ Wawancara dengan Bapak Kholid pada tanggal 23 Oktober 2020, pk1.09.00 WIB.

10 Nur Kholis, Manajemen Strategi Pendidikan, (Surabaya: UIN Sunan Ampel Press, 2013), hlm. 4.

${ }^{11}$ Ibid, hlm. 5.

$12 \mathrm{c}$

${ }^{13}$ Ibid, hlm. 7.

14 Taufiqurrahman, Manajemen Strategik, Jakarta: Fakultas Ilmu Sosial dan Ilmu Politik, Universitas Prof. Dr. Moestopo Beragama, 2016), hlm. 39.
}

mencapai tujuan. ${ }^{13}$ Berdasarkan penulisan dari Riva'i, bahwasanya tahapan manajemen stratgis dibagi menjadi tiga, yaitu perumusan strategi (formulating strategy), penerapan strategi (implementing strategi) dan evaluasi (evaluating). ${ }^{14}$

\section{Formulasi Strategi}

\section{a. Pengertian Formulasi Strategi}

Formulasi strategi merupakan proses yang dilakukan untuk menyiapkan rencana strategi (strategic plan). Formulasi strategi meliputi beberapa tahapan antara lain: penentuan visi, perumusan misi, nilai organisasi, dan pemilihan startegi untuk mencapai visi. ${ }^{15}$ Sedangkan menurut David, formulasi strategi mencakup pengembangan visi dan misi, identifikasi peluang dan ancaman dari faktor lingkungan eksternal, kesadaran terhadap kelemahan dan kekuatan dari faktor internal, pencapaian tujuan jangka panjang, dan perumusan strategi. ${ }^{16}$ Oleh karena itu, formulasi mencakup beberapa hal, antara lain:

1). Mengembangkan Pernyataan Visi dan Misi

Visi merupakan langkah awal yang dilakukan dalam merumuskan strategi. Visi merupakan gambaran besar masa depan yang ingin dicapai oleh organisasi secara realistik dalam kurun waktu tertentu. Sehingga visi akan menjawab "What do want to be?". ${ }^{17}$ Dalam hal ini, visi

15 Sumengen Sutomo, "Manajemen Strategi Organisasi Nirlaba", Jurnal Kesehatan Masyarakat Nasional, vol. 1, no 4, th. 2007, hlm. 178.

16 Taufiq Hidayat, "Formulasi Strategi Bisnis Dalam Upaya Meningkatkan Daya Saing Industri Batik Mliwis Putih di Desa Sobontoro Balen Bojonegoro", Jurnal Edutama, vol. 3, no. 1, th. 2016, hlm. 23.

17 Nur Kholis, Manajemen Strategi Pendidikan: Formulasi, Implementasi, dan Pengawasan, 
dirumuskan untuk
mengomunikasikan alasan
keberadaan organisasi dalam arti
tujuan dan tugas pokoknya. Visi
juga dimaksudkan untuk
memperhatikan framework
hubungan antara organisasi
dengan stakeholders. Selain itu,
visi juga digunakan sebagai
pernyataan sasaran utama kinerja
organisasi.

Sedangkan misi merupakan sebuah guidelines yang lebih pragmatis dan kongkrit. Misi dapat digunakan sebagai acuan pengembangan strategi dan aktivitas dalam lembaga atau organisasi. Misi merupakan deskripsi tentang apa yang dicitacitakan dan untuk siapa cita-cita tersebut. Menurut Rhobinson, misi dijadikan sebagai tujuan fundamental dan bersifat unik sebagai pembeda suatu organisasi dengan organisasi lainnya. Sehingga misi merupakan sebuah pernyataan mengenai hal-hal yang harus dicapai organisasi untuk mewujudkan visi yang telah ditetapkan dari awal. ${ }^{19}$

2). Identifikasi Lingkungan Internal Lingkungan internal merupakan keadaan di dalam organisasi yang menjadi kekuatan atau kelemahan dari suatu organisasi tersebut. Lingkungan internal dengan kekuatan yang lebih besar dari pada kelemahan
(Surabaya: UIN Sunan Ampel Press, 2014), hlm. 29.

18 Akdon, Strategic Managemen for Educational, (Bandung: Alfabeta, 2006), hlm. 94.

19 Nur Kholis, Manajemen Strategi Pendidikan: Formulasi, Implementasi, dan Pengawasan, (Surabaya: UIN Sunan Ampel Press, 2014), hlm. 31 .

${ }^{20}$ Novita Wahyu Setyowati, "Pengaruh Lingkungan Eksternal dan Lingkungan Internal Terhadap Keunggulan Bersaing Pada Industri Kecil dan akan mencerminkan kemampuan manajemen untuk mengelola perusahaan. Lingkungan internal mencakup segala aspek material atau non material yang dimiliki perusahaan dalam menjalankan usaha dan fungsinya. ${ }^{20}$ Menurut $\mathrm{J}$ Salusu, Aspek lingkungan internal meliputi: Struktur organisasi, sumber daya (dana dan tenaga), lokasi, fasilitas yang dimiliki, instregitas seluruh karyawan, dan integritas kepemimpinan. ${ }^{21}$

3). Identifikasi Lingkungan Eksternal

Lingkungan eksternal merupakan keadaan atau kondisi yang berada di luar organisasi yang dapat mempengaruhi perkembangan organisasi. Organisasi dapat dipengaruhi oleh lingkungan eksternal yang meliputi beberapa aspek seperti aspek ekonomi, sosial, budaya, pemerintahan, hukum, aspek teknologi dan aspek kompetitif. ${ }^{22}$

4). Menetapkan Tujuan Jangka Panjang

Penentuan tujuan merupakan langkah awal dalam perumusan strategi. Penentuan tujuan akan mengarahkan pelaksanannya sesuai dengan tujuan yang ingin dicapai. Sebagaimana pernyataan Mulyadi, "Tujuan adalah pernyataan luas tentang apa yang akan diwujudkan organisasi." 23
Menengah Bandung Jawa Barat", Jurnal Bisnis dan Manajemen, vol.5, no. 1, th. 2015, hlm. 14.

${ }^{21}$ Ibid, hlm. 17.

${ }^{22}$ Budi Lofian, "Identifikasi Faktor Eksternal dan Faktor Internal Yang Berpengaruh Terhadap Kinerja UKM Mebel Rotan di Jepara," Jurnal DISPROTEK, vol. 5, no. 2, th. 2014, hlm. 116.

${ }^{23}$ Novita Wahyu Setyowati, "Pengaruh Lingkungan Eksternal dan Lingkungan Internal Terhadap Keunggulan Bersaing Pada Industri Kecil dan 
Tujuan akan mengarahkan tentang apa yang hendak dikejar dalam kurun waktu yang lama.

Tujuan dapat diartikan sebagai hasil akhir yang dicari organisasi melalui eksistensi dua operasinya. Cara untuk mengukur dan mendefinisikan keberhasilan setiap tujuan dengan kreteria efesiensi yaitu dengan membandingkan antara masukan dan hasilnya. Selain itu, juga dapat melakukan cara untuk mengukur efektivitas yaitu membandingkan tingkatan tercapainya tujuan yang akan dicapai.

5). Pemilihan Strategi Alternatif

Pemilihan strategi
dilakukan apabila telah mengetahui faktor lingkungan baik eksternal maupun internal, sehingga organisasi dapat menetapkan kelemahan, kekuatan, ancaman, peluang serta telah mengkaji kembali tujuan yang ideal yang akan dicapai oleh organisasi. Dalam hal ini, organisasi akan memilih alternatif strategi yang dapat menunjang pencapaian tujuan yang telah ditetapkan. ${ }^{24}$ Adapun macammacam strategi alternatif tersebut antara lain:

a) Strategi stabilitas merupakan strategi yang diambil oleh organisasi karena beberapa faktor, yaitu tidak adanya peluang dari lingkungan, organisasi dalam posisi maturity, organisasi sudah merasa puas dengan pencapainnya atau keuntungan yang diperolehnya, adanya peningkatan jumlah produk karena dibarengi dengan

Menengah Bandung Jawa Barat", Jurnal Bisnis dan Manajemen, vol. 5, no. 1, th. 2015, hlm. 33.

${ }^{24} \mathrm{Ibid}, \mathrm{hlm} .51$. peningkatan jumlah penduduk serta manajer yang tidak berani mengambil resiko. Pada startegi stabilitas ini, perusahaan atau organisasi tidak akan menambah pasar, produk maupun peningkatan efesiensi di setiap bidang. ${ }^{25}$

b) Strategi ekspansi atau pengembangan merupakan strategi yang digunakan oleh organisasi dengan menambah produk baru atau mendirikan usaha baru. Perusahaan akan memiliki strategi ini apabila ia memiliki keinginan untuk meningkatkan usahanya yang sekarang. Selain itu, ia juga ingin meningkatkan prestasi kerja dan mengejar efektifitas. ${ }^{26}$

c) Strategi penciutan merupakan strategi yang digunakan oleh organisasi dengan mengurangi produk atau jasa, pasar atau pun fungsi karena beberapa hal. Selain itu, organisasi juga akan mengurangi kegiatan setiap unit yang mempunyai nilai arus kas min (-). Strategi ini biasanya digunakan oleh organisasi apabila organisasi tersebut tidak berjalan dengan baik. Selain itu, adanya hambatan dari lingkungan eksternal yang tidak mampu dikendalikan oleh kekuatan intern. $^{27}$

d) Strategi kombinasi merupakan strategi yang diterapkan oleh organisasi apabila tidak adanya dukungan dari lingkungan seperti perubahan lingkungan dengan kecepatan yang tidak sama, posisi produk berada di tingkat siklus yang berbeda di setiap lingkungan masyarakat, adanya siklus
${ }^{25}$ Ibid, hlm. 56.
${ }^{26}$ Ibid, hlm. 55.
${ }^{27}$ Ibid, hlm. 52. 
perekonomian yang tidak stabil dan pada saat produk berada di siklus stransisi. ${ }^{28}$

b. Fungsi Formulasi Strategi

Formulasi strategi sangat penting dilakukan oleh organisasi untuk mewujudkan tujuan jangka panjang. Formulasi strategi ini dirumuskan sebelum sebuah organisasi mengimplementasikan strategi tersebut. Maka dari itu, formulasi strategi akan memberikan kebijakan yang tepat, sehingga pada saat diimplementasikan oleh setiap devisi atau unit yang ada di dalam organisasi tersebut, formulasi strategi akan memberikan pengarahan yang jelas, memberikan tugas dan tanggungjawab sebaik mungkin. Apalagi melihat keadaan saat ini, perkembangan teknologi yang semakin canggih, perubahan zaman yang serba cepat, maka dari itu, perusahaan atau organisasi membutuhkan rencana strategis, sehingga proses maupun langkah yang diambil oleh organisasi tepat sasaran dan dapat dijalankan seefektif dan seefesien mungkin.

\section{Pembinaan Remaja Masjid}

Pembinaan remaja masjid merupakan berbagai aktivitas atau kegiatan kemasjidan yang dilakukan untuk mencetak remaja menjadi generasi muda yang sholeh, berakhlakul karimah, beriman, berilmu, berketrampilan dan berbudi luhur. $^{29}$ Sedangkan remaja

${ }^{28} \mathrm{lbid}, \mathrm{hlm} .53$.

29 Aslati, dkk., "Pemberdayaan Remaja Berbasis Masjid" (Studi Terhadap Remaja Masjid di Labuh Baru Barat), Jurnal Masyarakat Madani, vol. 3, no. 2, th. 2018, hlm.7.

${ }^{30}$ Ahmad Sholeh Muhlisin, "Pembentukan Karakter Melalui Pembinaan Remaja Islam Masjid (RISMA) Aththajirin Dusun Bandar Setia Bandar Agung merupakan salah satu periode transisi yang merupakan perkembangan manusia dari masa anak-anak menuju masa dewasa. Pada usia remaja ini, para remaja akan mengalami perubahan pada beberapa aspek yaitu aspek biologi, aspek psikologi maupun aspek sosial. ${ }^{30}$ Sehingga remaja membutuhkan binaan untuk menjadi generasi yang bertindak di atas dasar Islam. Pembinaan remaja masjid dimaksudkan untuk mendidik para generasi remaja menanamkan nilainilai dasar keimanan sehingga dapat membentengi diri remaja dari pergaulan bebas. Selain itu, pembinaan remaja juga mengarah pada pembentukan jati diri. Pembentukan jati diri ini akan memberikan manfaat pada diri remaja supaya tidak terombangambing dengan jalan hidup yang mereka tempuh. Selain itu, pembinaan juga berguna untuk mengembangkan potensi para remaja. ${ }^{31}$

Pembinaan remaja masjid dapat dilakukan dengan berbagai sarana atau cara yang diperlukan untuk mencapai tujuan yang diinginkan. Pembinaan ini tidak lain adalah untuk membentuk remaja yang beriman, berilmu dan beramal sholeh dalam rangka mengabdi kepada Allah dan menggapai ridhoNya. Pembinaan remaja masjid dapat dilakukan melalui beberapa susunan program. Susunan program tersebut kemudian akan ditindaklanjuti

Kecamatan Bandar Agung Negeri Suoh Lampung Barat." Skripsi. Fakultas Dakwah dan Ilmu Komunikasi, Universitas Negeri Raden Intan Lampung, th. 2019, hlm. 39.

${ }^{31}$ Aslati, dkk., "Pemberdayaan Remaja Berbasis Masjid”, Jurnal Masyarakat Madani, vol. 3, no. 2, th. 2018, hlm. 12. 
dengan berbagai aktivitas yang beragam. ${ }^{32}$

Dalam hal ini, remaja masjid akan membina anggotanya supaya menjadi orang yang beriman, bertaqwa, berketrampilan dan beramal shaleh. Di samping itu, mereka juga akan melakukan pembidangan kerja berdasarkan kebutuhan organisasi supaya dapat bekerja secara efektif dan efesien. Pembidangan kerja tersebut digunakan untuk mewadahi fungsifungsi organisasi yang disesuaikan dengan program kerja yang telah ditetapkan. Adapun pembidangan kerja tersebut antara lain: administrasi dan kesektariatan, keuangan, pembinaan anggota, perpustakaan atau informasi dan kesejahteraan umat. ${ }^{33}$

\section{MetodePenelitian}

Metode penelitian ini menggunakan pendekatan kualitatif dengan jenis penelitian studi kasus yaitu menganalisis fenomena-fenomena berdasarkan situasi sosial di objek penelitian. Sehingga penelitian ini tidak menggunakan data statistic, hitungan maupun matematik. Namun, data digali secara mendalam melalui observasi, dokumentasi dan wawancara. Penelitian ini dilakukan di Masjid Al-Falah Tuban yang berlokasi di Jl. Dr. Wahidin Sudiro Husodo No. 99 A Kelurahan Latsari Kecamatan Tuban Kabupaten Tuban, Jawa Timur. Wawancara dilakukan dengan 7 narasumber yaitu ketua remaja masjid, devisi keremajaan takmir masjid, wakil

\footnotetext{
${ }^{32} \mathrm{Ibid}$, hlm. 6 .

${ }^{33} \mathrm{Ibid}$, hlm. 7.

34 Bambang Subandi, Manajemen Organisasi dalam Hadits Nabi, (Surabaya: Nusantara Press, 2016), hlm. 74.
}

ketua remaja masjid, sekretaris, bendahara, devisi dakwah remaja masjid dan devisi perekonimian remaja masjid.

Proses analisis data dilakukan melalui transkip data, coding, kategorisasi data, penyajian data kemudian analisis data dan menarik kesimpulan.

\section{Hasil dan Pembahasan}

\section{Proses Penyiapan Rencana Strategi Pembinaan Remaja Masjid A-Falah.}

Untuk mengambil kebijakan strategis, pihak organisasi melakukan keputusan kebijakan dengan sangat hatihati. Maka dari itu, pihak manajemen membutuhkan perumusan yang matang.

Dalam proses perumusan rencana strategi, salah satu hal yang harus dilakukan adalah menganalisa lingkungan, baik dari segi profil maupun lingkungan luar organisasi. ${ }^{34}$ Dengan menganalisa lingkungan tersebut, pihak manajemen organisasi akan memperoleh informasi yang berguna untuk pembuatan kebijakan dalam suatu organisasi termasuk perumusan visi misi. Maka dari itu, informasi penting dapat dicari dari internal yang meliputi historis organisasi baik sumber daya manusia, keuangan, maupun produksi dan lain-lain. Sedangkan untuk eksternal, informasi penting dapat dicari melalui media elektronik maupun media cetak. ${ }^{35}$ Berdasarkan wawancara, observasi maupun dokumentasi, dalam proses perumusan rencana strategi ini, pihak pengurus inti dari Remaja Masjid Al-Falah telah melakukan beberapa hal, antara lain:

a). Analisis Lingkungan Eskternal

Proses perencanaan strategi pembinaan Remaja Masjid Al-Falah pertama yang dilakukan adalah

\footnotetext{
${ }^{35}$ Rahayu Puji Suci, Esensi Manajemen Strategis, (Sidoarjo: Zifatma Publisher), th. 2015, hlm. 10.
} 
menganalisis lingkungan eskternal. Lingkungan eksternal adalah faktor yang berada di luar lingkungan yang memiliki potensi dapat mempengaruhi organisasi. ${ }^{36}$ Faktor eksternal dapat dilihat dari beberapa aspek, seperti meliputi aspek ekonomi, aspek sosial budaya, demograsi dan lingkungan, aspek hukum, aspek politik, pemerintah dan aspek kompetitif. ${ }^{37}$ Oleh karena itu, organisasi harus mempertimbangkan faktor-faktor tersebut untuk merumuskan strategi. Melalui analisis lingkungan, perumusan visi juga tepat sesuai dengan perkembangan zaman.

Pada tahap ini, remaja masjid hanya lebih berfokus pada lingkungan eksternal. Karena keadaan luar organisasi atau faktor eksternal sangat menghawatirkan terhadap diri para remaja, seperti pergaulan bebas, kebebasan bermedia sosial, kemajuan teknologi yang semakin canggih, sehingga dapat memicu perbuatan negatif. Jadi, ada perbedaan antara kehidupan remaja dahulu dengan sekarang. Oleh karena itu, Badan Pengurus Harian atau pengurus inti harus selektif dalam membaca realita saat ini. Dalam hal ini, remaja masjid mencoba untuk menanggulangi ancaman-ancaman lingkungan luar organisasi tersebut dengan berbagai kegiatan yang nantinya dapat menunjang keberhasilan rencana strategis yang telah ditetapkan.

c).Musyawarah oleh pengurus inti terlebih dahulu.

Musyawarah sangat penting dilakukan. Karena organisasi tidak

36 Putu Rani Susanthi, "Analisis Lingkungan Internal dan Eksternal dalam Mencapai Tujuan Perusahaan", Jurnal Elektronik REKAMAN (Riset Ekonomi Bidang Manajemen dan Akuntansi Sekolah Tinggi Ilmu Ekonomi Galileo), vol.1. no. 1, th. 2017, hlm. 34.

${ }^{37}$ Budi Lofian, "Identifikasi Faktor Eksternal dan Faktor Internal Yang Berpengaruh Terhadap dimiliki oleh perorangan saja, namun ada banyak sumber daya manusia yang menjalankan organisasi tersebut. Oleh karena itu, sebelum merumuskan strategi yang nantinya dapat memberikan kelancaran jalannya organisasi yang sesuai dengan keadaan dan zaman, langkah yang harus dilakukan adalah musyawarah.

Dengan musyawarah ini, ide-ide dari perumus akan muncul, kemudian akan ada kesepakatan bersama. Karena dalam mengambil kebijakan harus sangat hati-hati, apalagi masalah rencana strategi. Rencana strategis tidak hanya berupa keindahan kata saja, namun juga pernyataan yang nantinya bisa diwujudkan bersama, oleh karena itu tidak semua sumber daya manusia organisasi ikut dalam musyawarah tersebut. ${ }^{38}$

Dalam hal ini, musyawarah hanya dilakukan oleh pengurus inti untuk menghasilkan rumusan yang strategis dengan dibantu oleh takmir bagian sie remaja. Setelah itu, musyawarah akan dilakukan oleh semua devisi organisasi.

c). Perumusan visi oleh pengurus inti

Visi merupakan pandangan jauh ke depan tentang bentuk organisasi, gambaran, atau citra yang akan dituju oleh organisasi. Visi dapat diartikan sebagai gambaran masa depan yang dicita-citakan organisasi untuk diraih dalam kurun waktu tertentu. Sehingga visi akan menjawab "What do want to be?". ${ }^{39}$ Dalam perumusan visi ini, ketua bersama dengan pengurus inti lainnya merumuskan visi organisasi dengan dibantu oleh takmir sie. Remaja,

Kinerja UKM Mebel Rotan di Jepara," Jurnal DISPROTEK, vol. 5, no. 2, th. 2014, hlm. 116.

38 Bambang Subandi, Manajemen Organisasi dalam Hadits Nabi, (Surabaya: Nusantara Press, 2016), hlm. 76.

39 Nur Kholis, Manajemen Strategi Pendidikan: Formulasi, Implementasi, dan Pengawasan, (Surabaya: UIN Sunan Ampel Press, 2014), hlm. 29. 
kemudian perumusan visi akan diserahkan oleh ketua takmir untuk mendapat persetujuan. Dalam hal ini perumusan visi hanya dilakukan oleh beberapa orang saja, supaya pernyataan visi sistematis, akurat dan jelas. ${ }^{40}$

Dalam perumusan visi ini, diperoleh visi "Menjadikan Remaja Masjid Al-Falah sebagai generasi muda yang bertaqwa kepada Allah SWT, berakhlak mulia, mandiri dan bermanfaat bagi sesama manusia". Alasan pemilihan visi tersebut adalah melihat kondisi zaman sekarang kemajuan teknologi yang semakin canggih, semakin maraknya pergaulan bebas yang tidak sulit dikendalikan. Sehingga dengan pondasi takwa, maka para remaja tidak akan melakukan halhal yang berbau negatif. Hal ini tentunya akan mencegah para remaja mengalami degradasi moral. Pada perumusan ini, visi dicita-citakan dalam kurun waktu 5 tahun ke depan. Karena kepengurusan remaja masjid berlangsung selama 5 tahun, maka dari itu visi juga akan diwujudkan dalam kurun waktu 5 tahun ke depan.

d) Berdoa

Setelah strategi yang beriorentasi dirumuskan, kemudian telah disepakati secara bersama, maka langkah selanjutnya adalah berdoa kepada Allah SWT. Meskipun dalam teori manajemen strategi tidak dianjurkan untuk berdoa, namun Nabi menganjurkan untuk selalu berdoa sebelum melakukan aktivitas. Melalui doa, Tuhan akan memberikan kemudahan dalam segala aktivitas dari berbagai hambatan, tantangan maupun ancaman. Namun berdoa dalam manajemen strategi adalah sebuah keyakinan untuk memperoleh pertolongan dari Allah. ${ }^{41}$

40 Bambang Subandi, Manajemen Organisasi dalam Hadits Nabi, (Surabaya: Nusantara Press, 2016), hlm. 75.

\section{Isi Rencana Strategi Pembinaan Remaja Masjid Al-Falah Tuban}

Adapun isi rencana strategi pembinaan Remaja Masjid Al-Falah adalah sebagai berikut:

a. Perumusan target program kegiatan

Isi dari perumusan rencana strategi pembinaan remaja masjid, salah satunya adalah diwujudkan dalam proses perumusan target program kegiatan. Target kegiatan ini harus dilakukan oleh semua devisi selama kepengurusan berlangsung dalam pantauan pengurus inti. Namun, jika suatu program kegiatan tidak jalan, maka program kegiatan tersebut akan direvisi dan dirumuskan ulang bersama pengurus inti.

Sebagaimana yang dikatakan oleh Hunger dan Thomas, bahwasanya perumusan strategi dilakukan oleh beberapa orang yang cenderung sedikit dibanding pelaksana itu sendiri. ${ }^{42}$ Dalam hal ini, perumusan target program kegiatan dilakukan oleh setiap devisi sesuai dengan programnya atas pengawasan ketua dan dilaksanakan oleh semua sumber daya manusia di dalam organisasi tersebut. Target program tersebut meliputi jadwal baik harian, bulanan, maupun tahunan, absensi kedatangan dan tabungan akhirat. Jadi setiap program kegiatan harus terjadwal dengan jelas, serta adanya SDM yang mengikuti kegiatan tersebut melalui absensi dan dari para remaja masjid memiliki tabungan akhirat dengan mengambil jerih payah mereka sendiri.

b.Mengukur pencapaian program kegiatan Dalam hal ini, program kegiatan bisa jelas tercapai apabila adanya perkiraan program kegiatan itu sukses tidaknya. Remaja masjid mengukur program

${ }^{41}$ Ibid, hlm. 44.

42 J. David Hunger dan Thomas L. Wheelen, Manajemen Strategis, hlm. 300. 
kegiatan itu tercapai apabila terdapat output atau hasil. Seperti dari devisi jurnalistik, maka ia harus menghasilkan sebuah tulisan yaitu berbentuk buletin dan buku rangkuman ceramah ngaji ahad pagi. Kemudian dari devisi minat bakat, maka ia harus bisa menampilkan remaja masjid di siaran radio dan juga TV Al-Falah dan lain sebagainya. Selain itu, pengukuran pencapaian itu juga dilihat dari maksimalnya kegiatan yang dapat memberi maslahat kepada semua masyarakat baik secara internal maupun secara eksternal. Dari sinilah, pentingnya penetapan tujuan untuk memberikan arah dalam pencapaian misi melalui pencapaian program dan sub program organisasi. ${ }^{43}$

3. Mengembangkan program kegiatan

Pengembangan program kegiatan dilakukan apabila remaja masjid mengetahui akan kelemahan dan kekuatan organisasi serta ancaman dan peluang dari luar organisasi yang dapat mempengaruhi organisasi. Oleh karena itu, pengurus remaja masjid harus tepat membaca SWOT supaya pengambilan strategi alternatif tepat guna.

Analisis SWOT adalah singkatan dari kekuatan dan kelemahan lingkungan internal serta peluang dan ancaman lingkungan eksternal. Dalam hal ini, ada 4 kuadran yaitu strategi SO, strategi ST, strategi WT. Pada strategi WO merupakan organisasi yang memiliki kekuatan secara internal, sehingga kekuatan itu dapat digunakan untuk memanfaatkan peluang eksternal. ${ }^{44}$

Remaja Masjid Al-Falah memiliki kekuatan dalam keuangan. Selain itu, juga mendapatkan dukungan penuh dari takmir masjid sebagai bapak organisasi remaja masjid. Masyarakat juga mendukung penuh terhadap kegiatan

43 Nur Kholis, Manajemen Strategi Pendidikan, (Surabaya: UIN Sunan Ampel Press, th. 2014), hlm. 34. remaja masjid, sehingga mereka ikut andil dalam menyumbang materi maupun tenaga demi kelancaran kegiatan remaja masjid. Maka dari itu, organisasi remaja masjid lebih menggunakan kekuatan internal tersebut untuk memanfaatkan peluang. Adanya youtube, TV, siaran radio merupakan fasilitas yang dimiliki AlFalah sehingga bisa digunakan oleh remaja masjid untuk selalu mengembangkan diri. Maka, dengan adanya kemudahan bermedia sosial ini aset tersebut dapat dimanfaatkan oleh remaja masjid untuk menyiarkan agama.

Melihat beberapa peluang dan kekuatan yang ada, Remaja Masjid AlFalah mengambil kebijakan strategi ekspansi yaitu dengan memperbanyak program kegiatan pembinaan remaja masjid.

Pembinaan remaja masjid dapat dilakukan melalui beberapa susunan program. Susunan program tersebut kemudian akan ditindaklanjuti dengan berbagai aktivitas yang beragam. ${ }^{45}$ Maka dari itu, dengan penambahan kegiatan artinya remaja Masjid AlFalah dalam fase pengembangan organisasi yang outputnya adalah untuk kemaslahatan bersama dan tercapainya Ridho Allah SWT.

\section{Kesimpulan}

Dalam proses penyiapan rencana strategi pembinaan remaja masjid, organisasi Remaja Masjid Al-Falah melakukan: (1) analisis lingkungan eksternal dengan melihat kondisi eksternal yang dapat mempengaruhi karakter remaja. (2) Kemudian setelah melihat kondisi eksternal tersebut,

\footnotetext{
${ }^{44}$ Rahayu Puji Suci, Esensi Manajemen Strategis, (Sidoarjo: Zifatma Publisher), th. 2015, hlm. 70.

${ }^{45}$ Ibid, hlm. 6.
} 
remaja masjid merumuskan visi yang harus dicapai untuk lima tahun ke depan. (3) Ia juga melakukan musyawarah. Musyawarah dilakukan oleh badan pengurus harian remaja masjid terlebih dahulu bersama takmir masjid devisi keremajaan. Setelah itu, musyawarah dilakukan bersama seluruh jajaran pengurus remaja masjid. (4) Berdoa untuk kelancaran segala program yang akan dijalankan nanti.

Adapun isi dari perencanaan strategi pembinaan Remaja Masjid AlFalah antara lain: 1) perumusan target program kegiatan. Perumusan tersebut berupa jadwal program kegiatan seperti harian, mingguan, bulanan, tahunan serta absesnsi kehadiran. (2) Remaja masjid juga mengukur pencapaian program kegiatan dengan melihat outputnya atau hasil yang dicapai oleh setiap program kegiatan, misalnya $\mathrm{MC}$ yang menghasilkan penampilan $\mathrm{MC}$ pada saat pengajian ahad pagi, adanya penerbitan buletin, buku saku berisi rangkuman ceramah kiai yang sudah ditulis oleh remaja masjid serta program kegiatan yang dijalankan dapat memberi manfaat ke semua orang. (3) Mengembangkan program kerja dengan membuat program kegiatan baru yang dapat memberi maslahat untuk umat sebagai bentuk memakmurkan masjid, syiar agama dan juga pengembangan potensi remaja masjid (strategi ekspansi)

\section{Daftar Pustaka}

Akdon. 2006. Strategic Managemen for Educational, (Bandung: Alfabeta).

Aslati, dkk. 2018. "Pemberdayaan Remaja Berbasis Masjid (Studi Terhadap Remaja Masjid di Labuh Baru Barat"), Jurnal Masyarakat Madani, Vol:3 (2).
Fauzi, Anis. 2006. "Masjid Sebagai Pusat Pembinaan Remaja", Jurnal AlQalam. Vol: 23 (2).

Hidayat, Taufiq. 2016. "Formulasi Strategi Bisnis Dalam Upaya
Meningkatkan Daya Saing Industri Batik Mliwis Putih di Desa Sobontoro Balen Bojonegoro". Jurnal Edutama. Vol: 3 (1)

Ilyas, Muhammad, M. Sarbini, dan Ali Maulida. 2016. "Upaya Pengurus, Dewan Kemakmuran Masjid (DKM) Dalam Pembinaan Keberagaman Remaja: Studi Kasus pada Remaja Masjid Ahlul Khoir RT 08 RW 13 Kelurahan Cilebut Timur Kecamatan Sukareja Kabupaten Bogor", Prosiding Al-Hidayah Pendidikan Agama Islam.

Kholis, Nur. 2013. Manajemen Strategi Pendidikan. (Surabaya: UIN Sunan Ampel Press).

Lofian, Budi. 2014. "Identifikasi Faktor Eksternal dan Faktor Internal Yang Berpengaruh Terhadap Kinerja UKM Mebel Rotan di Jepara," Jurnal DISPROTEK. Vol: 5 (2).

Muhlisin, Ahmad Sholeh. 2019. "Pembentukan Karakter Melalui Pembinaan Remaja Islam Masjid (RISMA) Aththajirin Dusun Bandar Setia Bandar Agung Kecamatan Bandar Agung Negeri Suoh Lampung Barat." Skripsi. Fakultas Dakwah dan Ilmu Komunikasi, Universitas Negeri Raden Intan Lampung.

Nawawi, Ismail. 2010. Manajemen Strategik Sektor Publik. (Jakarta: CV Dwiputra Pustaka Jaya) 
Observasi pada tanggal 16 November 2020.

Setyawan, Roby. 2015. "Penerapan Analisis SWOT Sebagai Landasan Merumuskan Strategi Pemasaran Usaha Jasa Sewa Mobil 'Aman-Amin Transport Tours and Travel Ambarketawang Sleman". Skripsi. Universitas Negeri Yogyakarta.

Setyowati, Novita Wahyu. 2015. "Pengaruh Lingkungan Eksternal dan Lingkungan Internal Terhadap Keunggulan Bersaing Pada Industri Kecil dan Menengah Bandung Jawa Barat." Jurnal Bisnis dan Manajemen. Vol: 5 (1)

Subandi, Bambang. 2016. Manajemen Organisasi dalam Hadits Nabi. (Surabaya: Nusantara Press).

Suci, Rahayu Puji. 2015. Esensi Manajemen Strategi. Sidoarjo: Zifatma Publisher.

Susanthi, Putu Rani. 2017. “Analisis Lingkungan Internal dan Eksternal dalam Mencapai Tujuan Perusahaan". Jurnal Elektronik REKAMAN (Riset Ekonomi Bidang Manajemen dan Akuntansi Sekolah Tinggi Ilmu Ekonomi Galileo). Vol: 1 (1).

Sutomo, Sumengen. 2007. "Manajemen Strategi Organisasi Nirlaba", KESMA: Jurnal Kesehatan Masyarakat Nasional. Vol: 1(4).

Taufiqurrahman. 2016. Manajemen Strategik, Jakarta: Fakultas Ilmu Sosial dan Ilmu Politik, Universitas Prof. Dr. Moestopo Beragama.
Wawancara dengan Bapak Kholid pada tanggal 23 Oktober 2020, pk1.09.00 WIB.Yunus, Eddy. Manajemen Strategis. Penerbit Andi. 